\title{
Chemical impact on the hydro-mechanical behaviour of high-density FEBEX bentonite
}

\author{
E. Castellanos ${ }^{\mathrm{a}, 1}$, M.V. Villar ${ }^{\mathrm{b}, *}$, E. Romero ${ }^{\mathrm{a}, 1}$, A. Lloret $^{\mathrm{a}, 1}$, A. Gens ${ }^{\mathrm{a}, 1}$ \\ ${ }^{a} U P C$, Universitat Politècnica de Catalunya, Jordi Girona 1-3, 08034 Barcelona, Spain \\ ${ }^{\mathrm{b}}$ CIEMAT - Centro de Investigaciones Energéticas, Medioambientales y Tecnológicas, Avd. Complutense 22, 28040 Madrid, Spain
}

\section{A R T I C L E I N F O}

Article history:

Available online 14 October 2008

\section{Keywords:}

Bentonite

Swelling

Permeability

Salinity

HLW disposal

\begin{abstract}
A B S T R A C T
The effect of the salinity of the saturating fluid on the hydro-mechanical properties of the FEBEX compacted bentonite was investigated by means of swelling, compressibility and permeability tests in which deionised water and solutions of different concentrations and compositions were used as saturating fluids. The solutions were chosen to simulate natural and extreme conditions in a high-level radioactive waste repository excavated in crystalline or clay host rocks. The swelling capacity of the bentonite decreases with the increase in salinity of the pore water, although this difference becomes less patent for high vertical loads and high densities and when the salinity of the solution is very low. The samples saturated with solutions containing high concentration of ions are also less deformable and consolidate more rapidly than the samples saturated with low-salinity solutions. The hydraulic conductivity of the highly compacted saturated FEBEX bentonite increases when high-salinity permeants are used, especially for low densities and when the stress level is low. The influence of the composition of the solution on the hydro-mechanical properties of the bentonite was also checked.
\end{abstract}

(c) 2008 Elsevier Ltd. All rights reserved.

\section{Introduction}

The investigation reported in this paper was carried out in the context of research projects related to the disposal of high-level radioactive wastes (HLW) in deep geological repositories. A system of natural and artificial barriers will be constructed to isolate the wastes from the host rock and the biosphere. The host rocks that are most widely considered, especially in Europe, are granites, clays and salts. As part of the engineered barrier of a HLW repository, bentonite - a clay material consisting mainly of smectite will be used as sealing material in most disposal concepts and will be placed around the waste containers in contact with the host rock. Bentonite was chosen as sealing material because of its low permeability, swelling capacity and retention properties, among other features. Its role is to delay the arrival of groundwater to the waste canister by the combined effect of low permeability and swelling capacity, the latter favouring the sealing of preferential pathways; to protect the canister against mechanical damage; and to retard the migration of radionuclides, once the canister fails, by retention processes. In a deep geological repository the type, salinity and geochemical composition of the water reaching the

\footnotetext{
* Corresponding author. Fax: +3491346 6542.

E-mail addresses: jose.ernesto.castellanos@upc.es (E. Castellanos),mv.villar@ ciemat.es (M.V.Villar), enrique.romero-morales@upc.es (E. Romero), antonio.lloret@ upc.es (A. Lloret), antonio.gens@upc.es (A. Gens).

1 Fax: +34934016504.
}

bentonite barrier will depend on the type of host rock, the interaction with other elements of the repository (e.g. concrete) and the modifications induced by the bentonite itself.

It is known that the behaviour of clayey materials is strongly dependent on the physico-chemical interactions between clay particles and pore fluid chemistry. Smectites are phyllosilicates made up of piled laminae with exchangeable cations and layers of water between them. The piling of clay laminae forms primary particles. The thickness of the primary particles varies depending on the hydration state. When two particles are located close to each other, their electric double layers (DDL) interact, inducing a repulsion whose magnitude is partly conditioned by the chemistry of the pore water. According to the DDL theories, the thickness of the DDL decreases as the saline concentration of the water in the pores increases. Consequently, for a given porosity, the effective pore size of the clay would increase with increasing concentration of the solution, with the corresponding increase in permeability. In turn, the swelling capacity of the clay increases with the thickness of the DDL.

Since the most important geotechnical properties to be taken into account to asses the correct performance of the bentonite barrier of a HLW repository are its hydraulic conductivity, swelling ability and compressibility, this paper presents results of experimental studies on the effect of changes in pore water composition on the hydro-mechanical properties of a sealing material statically compacted to high-density, the Spanish FEBEX bentonite. The research was carried out in the framework of FEBEX (Full-scale 
Engineered Barriers Experiment in Crystalline Host Rock), a project for the study of the near field for a HLW repository in crystalline rock according to the Spanish concept: the waste canisters are placed horizontally in drifts and surrounded by a clay barrier constructed from highly compacted bentonite blocks (ENRESA, 2000, 2006a). The tests were performed in two laboratories, at UPC (Universitat Politècnica de Catalunya) and CIEMAT (Centro de Investigaciones Energéticas, Mediambientales y Tecnológicas), and a wide range of salinities, as well as several representative dry densities, were tested. The range of salinities expected for the groundwater of granitic and clay host rocks were broadly covered, by taking into account not only the initial salinities of the groundwater, but also the progressive incorporation of ionic species as the groundwater migrates through the barrier and the possible concentration increases. Fig. 1 illustrates the local increase in the salinity of the pore water of the barrier caused by the processes associated to water advection: dissolution of soluble species of the bentonite in the more hydrated areas, transport with the water front, and local increases in concentration as the hydration front moves. The Figure shows the analyses performed in samples taken after dismantling of the FEBEX in situ test at the Grimsel Test Site (Switzerland). This test simulated the conditions of the bentonite barrier of a HLW repository at real scale and under natural conditions. The gallery was excavated in granite and the waste container was mimicked by a heater whose surface temperature was kept at $100^{\circ} \mathrm{C}$. The test was dismantled after five years operation (ENRESA, 2006a,b)

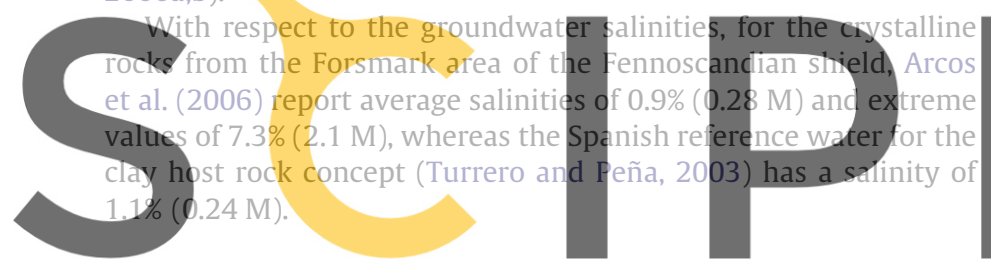

2. Material

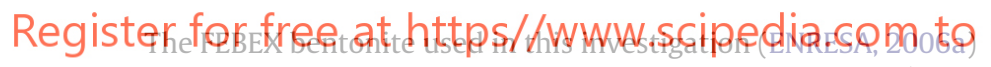
was obtained from the Cortijo de Archidona deposit, Almería, SE Spain. The material presents a content of montmorillonite higher than $90 \%$, the remaining minerals being small amounts of quartz, plagioclase, cristobalite, K-feldspars, trydimite and calcite. The material has a liquid limit of $102 \pm 4 \%$, a plastic limit of $53 \pm 3 \%$, a

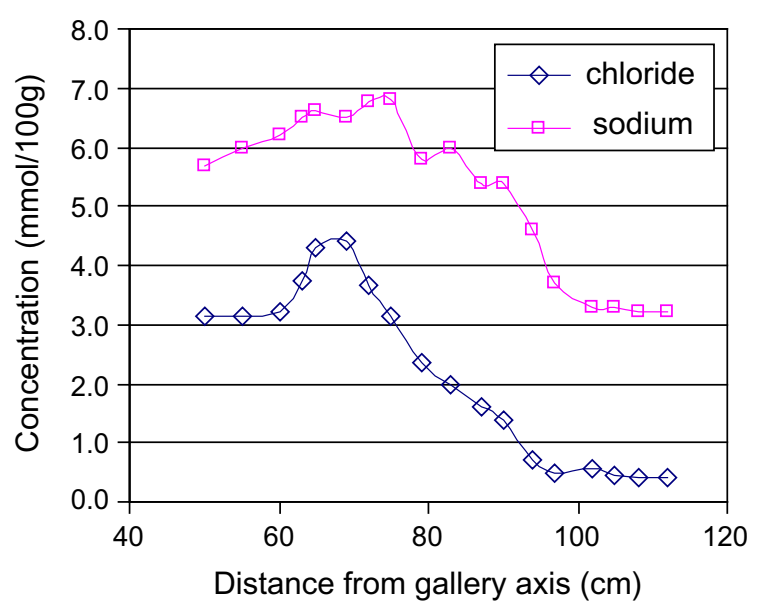

Fig. 1. Chloride and sodium concentration measured in aqueous extracts from samples taken along a vertical section of the bentonite barrier after 5 years of operation of the FEBEX in situ test (the heater diameter - placed concentrically with the gallery and simulating the waste container - was $49 \mathrm{~cm}$ ) (modified from ENRESA, 2006a,b). specific gravity for the soil particles of $2.70 \pm 0.04$ and a total specific surface area of $725 \mathrm{~m}^{2} / \mathrm{g}$. The hygroscopic water content in equilibrium with the laboratory atmosphere is $13.7 \pm 1.3 \%$. The cation exchange capacity (CEC) varies from 96 to $102 \mathrm{meq} / 100 \mathrm{~g}$, and the major exchangeable cations are $\mathrm{Ca}(35-42 \mathrm{meq} / 100 \mathrm{~g}), \mathrm{Mg}$ (31-32 meq/100 g), Na (24-27 meq/100 g) and $\mathrm{K}(2-3 \mathrm{meq} / 100 \mathrm{~g})$.

The saturated permeability to deionised water $\left(k_{\mathrm{w}}, \mathrm{m} / \mathrm{s}\right)$ of FEBEX bentonite samples that were compacted at different dry densities, is exponentially related to dry density $\left(\rho_{\mathrm{d}}, \mathrm{g} / \mathrm{cm}^{3}\right)$. The values of permeability to deionised water for dry densities around 1.6 $\mathrm{g} / \mathrm{cm}^{3}$ are in the order of $10^{-14} \mathrm{~m} / \mathrm{s}$. A distinction may be made between two different empirical fittings depending on the density interval (Villar, 2002): for dry densities of less than $1.47 \mathrm{~g} / \mathrm{cm}^{3}$ :

$\log k_{\mathrm{w}}=-6.00 \rho_{\mathrm{d}}-4.09$

for dry densities in excess of $1.47 \mathrm{~g} / \mathrm{cm}^{3}$ :

$\log k_{\mathrm{w}}=-2.96 \rho_{\mathrm{d}}-8.57$

The variation in the experimental values with respect to these fittings is smaller for low densities than it is for higher values, with an average - in relative values - of $30 \%$.

The swelling pressure $\left(P_{S}, \mathrm{MPa}\right)$ of FEBEX samples compacted with their hygroscopic water content and flooded with deionised water up to saturation can be related to dry density $\left(\rho_{\mathrm{d}}, \mathrm{g} / \mathrm{cm}^{3}\right)$ through the following equation (Villar, 2002):

\section{$\ln P_{\mathrm{s}}=6.77 \rho_{\mathrm{d}}-9.07$}
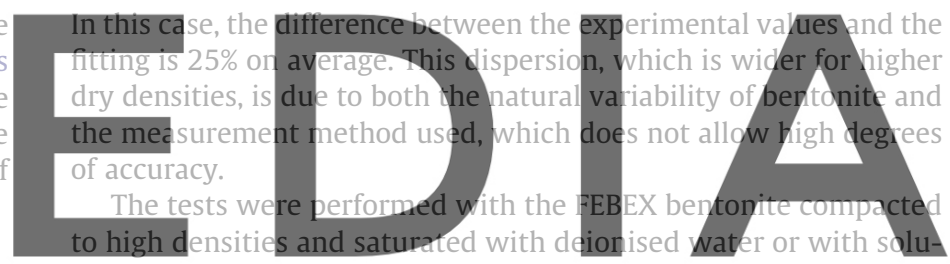

tions at room temperature. The solutions used were classified in low and high-salinity solutions. The first ones represent conditions

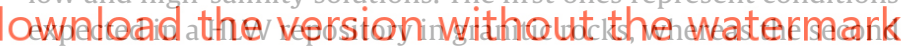
ones represent extreme conditions and were chosen because they allow a more systematic study of the effect of salinity.

Two low-salinity solutions were used, termed as saline and granitic (Table 1). The granitic solution simulates the conditions of the outer part of the barrier, and the saline water simulates the situation in the internal part of the barrier, where water is loaded with ionic species from the bentonite, dissolved during water inward movement. The granitic water is a commercial, rather diluted water $(0.005 \mathrm{M}, 0.02 \%$ salinity) from a Spanish granitic massif. The saline water used has a chemical composition similar to that of the bentonite interstitial water (Fernández and Cuevas, 1998), but simplified to include only the major elements. Its salinity is $0.76 \%(0.22 \mathrm{M})$, the main ions being chloride and sodium.

$\mathrm{NaCl}$ and $\mathrm{CaCl}_{2}$ solutions of different concentrations, always higher than $0.1 \mathrm{M}$, were used as high-salinity solutions. The osmo-

Table 1

Chemical composition of the low-salinity solutions.

\begin{tabular}{lll}
\hline Element $(\mathrm{mmol} / \mathrm{L})$ & Granitic & Saline \\
\hline $\mathrm{Cl}^{-}$ & 0.37 & 100 \\
$\mathrm{SO}_{4}^{2-}$ & 0.15 & 15 \\
$\mathrm{HCO}_{3}^{-}$ & 2.36 & \\
$\mathrm{Mg}^{2+}$ & 0.39 & 15 \\
$\mathrm{Ca}^{2+}$ & 1.12 & 10 \\
$\mathrm{Na}^{+}$ & 0.48 & 80 \\
$\mathrm{~K}^{+}$ & 0.026 & 7 \\
$\mathrm{pH}$ & 8.3 & 0.22 \\
$\mathrm{M}$ & 0.005 & 0.76 \\
Salinity (\%) & 0.02 & \\
\hline
\end{tabular}


Table 2

Osmotic suction of some of the solutions used as measured by psychrometric techniques (in MPa).

\begin{tabular}{|c|c|c|c|c|c|}
\hline $\mathrm{NaCl} 0.5 \mathrm{M}$ & $\mathrm{NaCl} 2.0 \mathrm{M}$ & $\mathrm{NaCl} 5.5 \mathrm{M}$ & $\mathrm{CaCl}_{2} 0.5 \mathrm{M}$ & $\mathrm{CaCl}_{2} 2.0 \mathrm{M}$ & $\mathrm{CaCl}_{2} 5.5 \mathrm{M}$ \\
\hline 2.2 & 10 & 33 & 3.2 & 18 & 54 \\
\hline
\end{tabular}

tic pressures corresponding to some of the solutions were measured using psychrometric techniques (Romero, 1999); they are indicated in Table 2.

The low-salinity solutions were used in the tests performed at CIEMAT laboratories (Madrid, Spain), whereas the high-salinity solutions were used in the tests performed at UPC (Barcelona, Spain).

\section{Methods}

\subsection{Swelling pressure}

\subsubsection{Tests with low-salinity solutions}

The swelling pressure tests performed at CIEMAT were carried out in oedometer frames and conventional oedometer cells, in which the surface of the sample was reduced in order to counteract the high forces expected. The initial height of the specimens was $12.0 \mathrm{~mm}$ and their cross-section was 998 or $1140 \mathrm{~mm}^{2}$. The samples were confined in rings preventing them from deforming laterally, and between two porous stones at the upper and lower surfaces.

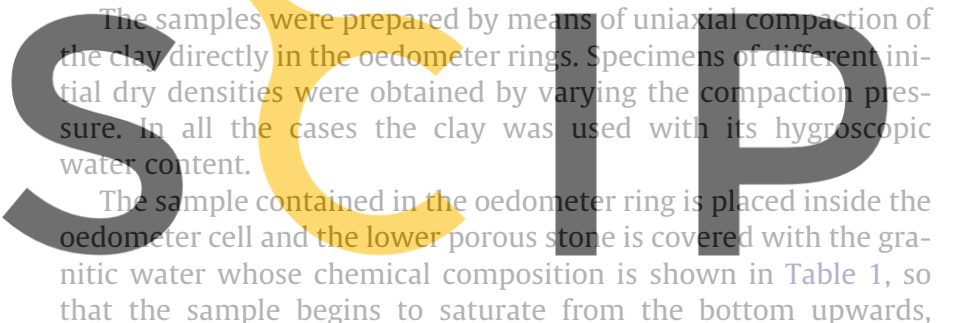

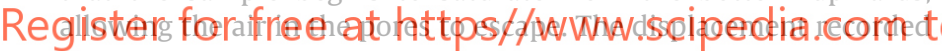

by a dial gauge as the sample saturates is observed, and swelling of the sample is prevented by the application of loads. Ideally the reading of the dial gauge shail not drift excessiveiy from the initiai value (within an uncertainty of $\pm 0.005 \mathrm{~mm}$ ), thus preventing both the swelling and the consolidation of the sample. The test is considered to be completed when, under a constant vertical load, no strain within the resolution of the gauge is observed for at least $24 \mathrm{~h}$. The duration of the tests was dependent on the dry density of the samples, with an average experimental duration of 4 days.

Once the sample is removed from the oedometer, its water content is checked by oven-drying at $110^{\circ} \mathrm{C}$ during $24 \mathrm{~h}$.

\subsubsection{Tests with high-salinity solutions}

The effect of water salinity on swelling pressure was investigated at UPC by measuring the swelling pressure of bentonite that was saturated under isochoric conditions using deionised water and solutions of $\mathrm{NaCl}(0.1,2.5,5.5,6.3 \mathrm{M})$ and $\mathrm{CaCl}_{2}(4.2 \mathrm{M})$. Initially, the bentonite was compacted at a dry density of $1.65 \mathrm{~g} /$ $\mathrm{cm}^{3}$ at hygroscopic conditions.

Some tests were performed in a conventional oedometer, in which the lever arm was fixed to prevent the swelling of the clay and the swelling force developed upon flooding was measured by means of a load cell (Lloret et al., 2003). Other tests were performed in the small isochoric cells shown in Fig. 2 (Hoffmann et al., 2007). In this case, an overpressure of $0.2 \mathrm{MPa}$ was applied to the water input to reduce the duration of the tests and a calibrated strain gauge was used to measure the swelling pressure. In all the tests, the thickness of the specimens was $10.5 \mathrm{~mm}$ and the diameter was $50.0 \mathrm{~mm}$.

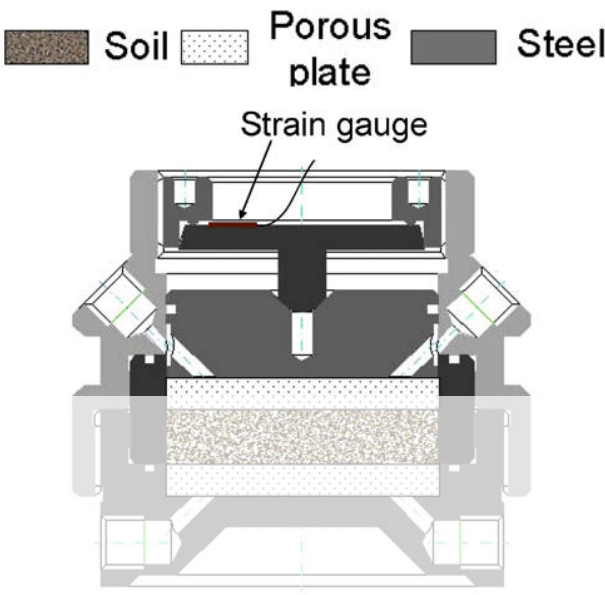

Fig. 2. Schematic representation of the isochoric cell designed by CIMNE to determine swelling pressure.

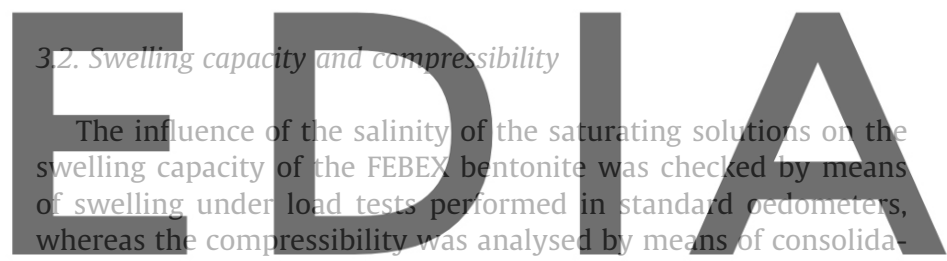

tion tests performed after the swelling stage of some of the swelling under load tests performed with high-salinity solutions.

\section{download the version without the watermark 3.2.1. Tests with low-salinity solutions}

The swelling capacity of the bentonite was determined by CIEMAT on samples compacted at dry densities of $1.50,1.60$ and $1.70 \mathrm{~g} / \mathrm{cm}^{3}$ with its hygroscopic water content (around 14\%), saturated in oedometers under different vertical loads. The material was compacted inside the cell ring using static uniaxial compaction. The average vertical stresses applied to obtain specimens of 36-38 mm diameter and $12 \mathrm{~mm}$ height were 13, 19 and $37 \mathrm{MPa}$ for the nominal dry densities of $1.5,1.6$ and $1.7 \mathrm{~g} / \mathrm{cm}^{3}$, respectively. Once in the oedometer, vertical pressures of $0.1,0.5,1.0,1.5,2.0$ or 3.0 MPa were applied to the samples. Immediately afterwards, the samples were flooded at atmospheric pressure from the bottom porous plate. Deionised, saline and granitic waters (Table 1) were used as saturation liquid. The swelling strain experienced by the specimens upon saturation was recorded as a function of time until stabilisation. The water content of the specimens was determined at the end of the tests.

\subsubsection{Tests with high-salinity solutions}

The high-salinity tests were performed at UPC with samples statically compacted to a dry density of $1.65 \mathrm{Mg} / \mathrm{m}^{3}$ at their hygroscopic water content (13.7\%). Compaction was carried out in the oedometer ring at a vertical displacement rate of $0.2 \mathrm{~mm} / \mathrm{min}$ and at a maximum vertical stress of $23.0 \mathrm{MPa}$. Specimens were $10.5 \mathrm{~mm}$ high and $50 \mathrm{~mm}$ in diameter. Once in the oedometers, the samples were gradually loaded at constant water content up to the vertical stress of the flooding stages $(0.02,0.5$ or $2.0 \mathrm{MPa})$. Since the load applied was lower than the compaction stress, the samples remained in over-consolidated state. Afterwards, the 
specimens were soaked under load using either distilled water or $\mathrm{NaCl}$ and $\mathrm{CaCl}_{2}$ solutions with concentrations of $0.5,2.0$ and $5.5 \mathrm{M}$. In the soaking stages, the time necessary to reach the stabilization of vertical displacements was about 5 days, but the whole stage was extended to two weeks.

To analyse the compressibility of the bentonite in some of the tests, after the soaking stage, the saturated bentonite was gradually loaded up to $2.0 \mathrm{MPa}$ under oedometer conditions. The unloading stage was performed in two steps. The followed stress paths are presented in Fig. 3.

The evolution of the sample deformation over time was interpreted using a non-linear curve-fitting algorithm, in order to determine the parameters used in the consolidation analysis by following Terzaghi's theory (Romero, 1999). The dial displacement of the oedometer $d$ under an effective stress increment can be theoretically expressed as

$d=d_{0}+\frac{2 h}{E_{m}} \delta\left(\sigma_{v}-u_{w}\right) \bar{U}\left(t, C_{v}\right)+2 h C_{\alpha} \log \left(t / t_{90}\right)$

where $d_{0}$ is the initial compression, mainly due to the equipment deformability, $2 h$ the mean thickness of the specimen, $E_{m}$ the drained constrained modulus of elasticity, $\bar{U}\left(t, C_{v}\right)$ the average degree of consolidation, which is a function of time $t$ and of the coefficient of consolidation $C_{v}$ (Lambe and Whitman, 1979; Das, 1983), $C_{\alpha}$ the coefficient of secondary consolidation and $t_{90}$ the time required for $90 \%$ of average consolidation.
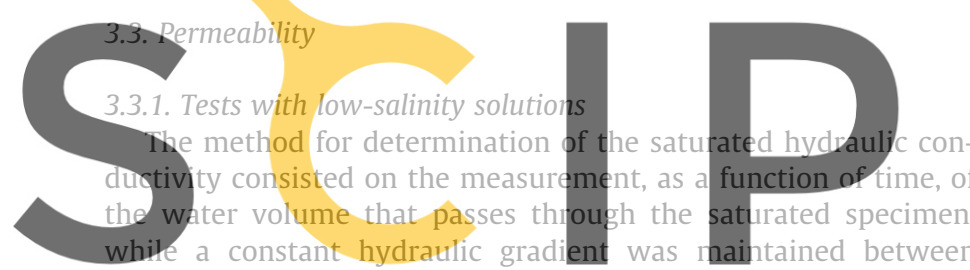
top and bottom (Villar and Lloret, 2001). The specimen was confined in a cylindrical rigid cell that prevented any change of the

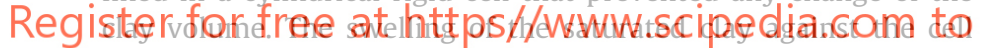
wall guaranteed a perfect contact between clay and cell, conse-

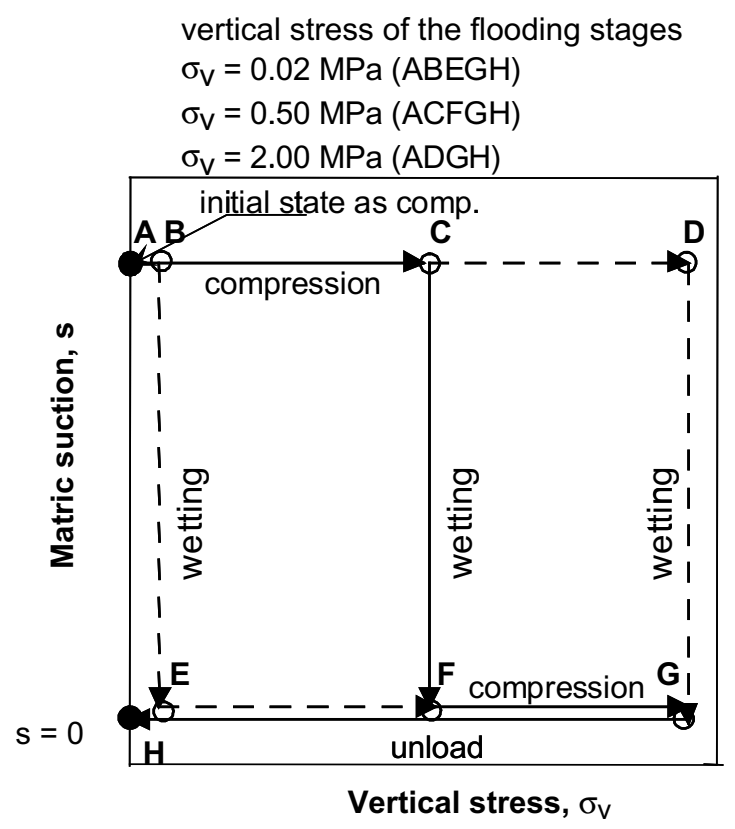

Fig. 3. Stress paths followed under oedometer conditions in the swelling and compressibility tests performed by UPC. quently avoiding a preferential pathway. The cells were made of stainless steel and had an inner section of $1963 \mathrm{~mm}^{2}$ and a height of $25 \mathrm{~mm}$. Porous stones were placed at the top and bottom of the specimen, which was saturated by injecting water through the porous stones at a pressure of $0.6 \mathrm{MPa}$. Once the sample saturated, the injection pressure in the lower part of the cell was increased, and the water outflow through the upper outlet of the cell was measured with an automatic volume change device. The permeability coefficient was calculated applying directly the Darcy's law. Hydraulic gradients between 3600 and 24,400 were applied for the determinations with granitic water, and between 400 and 18,000 for the determinations with saline water, depending on the dry density of the clay. It was demonstrated that, for this range of hydraulic gradients, the hydraulic conductivity value obtained is independent of the hydraulic gradient applied (Villar, 2002).

The determinations were performed using deionised or granitic water as saturating fluids and permeants (Table 1 ).

\subsubsection{Tests with high-salinity solutions}

The hydraulic conductivity of the bentonite when high-salinity solutions are used was obtained indirectly from the backanalysis of the vertical strain evolution measured during the compression stages performed in oedometer conditions after the saturation of the bentonite, following the methodology described in Section 3.2.2. Once the modulus of elasticity and the consolidation coefficient are known, the permeability can be calculated, since it is re-
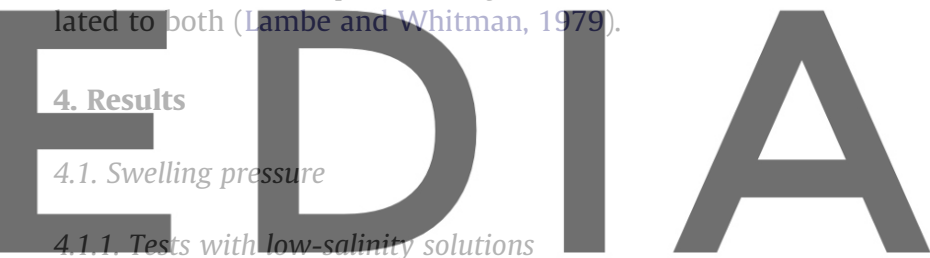

The determination of swelling pressure was performed at CIEMAT on specimens manufactured from the clay with its hygrq-

granitic water to saturate the sample (Villar, 2002). The results obtained are shown in Fig. 4, which also includes the empirical fitting of Eq. (3) obtained for samples saturated with deionised water. Taking into account the dispersion of the data obtained for this parameter, which is $25 \%$ on average (see Section 2), it may be concluded that the values obtained using granitic water

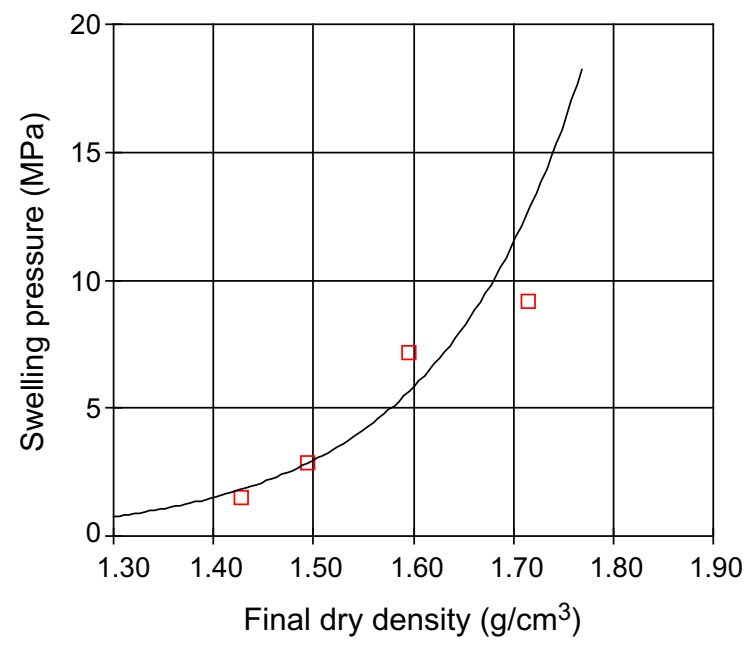

Fig. 4. Swelling pressure obtained for clay saturated with deionised (line, Eq. (3)) and granitic water (symbols). 
Table 3

Summary of swelling pressure tests using $\mathrm{NaCl}$ and $\mathrm{CaCl}_{2}$ solutions for bentonite compacted at $\rho_{\mathrm{d}} 1.65 \mathrm{~g} / \mathrm{cm}^{3}$.

\begin{tabular}{|c|c|c|c|c|c|}
\hline Test & Cell & Solution & Liquid injection pressure (MPa) & Time to reach $P_{s}$ (days) & Swelling pressure (MPa) \\
\hline 1 & Conventional oedometer & Distilled water & 0.0 & 15 & 4.5 \\
\hline 2 & Isochoric cell & Distilled water & 0.2 & 7 & 4.4 \\
\hline 3 & Isochoric cell & Distilled water & 0.2 & 8 & 4.4 \\
\hline 4 & Conventional oedometer & $0.1 \mathrm{M} \mathrm{NaCl}$ & 0.0 & 13 & 4.0 \\
\hline 5 & Conventional oedometer & $2.5 \mathrm{M} \mathrm{NaCl}$ & 0.0 & 4 & 2.9 \\
\hline 6 & Conventional oedometer & $5.5 \mathrm{M} \mathrm{NaCl}$ & 0.0 & 2 & 2.6 \\
\hline 7 & Isochoric cell & $6.3 \mathrm{M} \mathrm{NaCl}$ & 0.2 & 2 & 2.4 \\
\hline 8 & Isochoric cell & 4.2 $\mathrm{M} \mathrm{CaCl}_{2}$ & 0.2 & 5 & 2.8 \\
\hline
\end{tabular}

do not differ much from those that would have been obtained for the same densities with deionised water.

\subsubsection{Tests with high-salinity solutions}

The effect of high water salinity on swelling pressure was investigated by measuring the swelling pressure of bentonite that was compacted to a nominal dry density of $1.65 \mathrm{~g} / \mathrm{cm}^{3}$ and saturated under isochoric conditions using solutions of $\mathrm{NaCl}$ and $\mathrm{CaCl}_{2}$ of different concentrations. Table 3 shows a summary of the tests performed and the results obtained. Fig. 5 shows the evolution over time of the swelling pressure measured in some tests. It can be seen that an increase in salt concentration reduces the swelling pressure. The reduction of the time necessary to reach the final swelling pressure when the concentration of $\mathrm{NaCl}$ increases may be attributed to an increase in the perme-

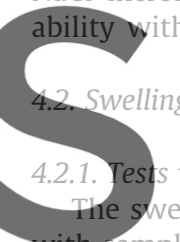
yith salinity.
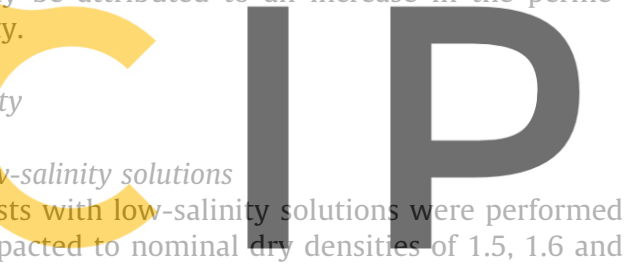

$1.7 \mathrm{~g} / \mathrm{cm}^{3}$ saturated under different vertical loads from 0.1 to

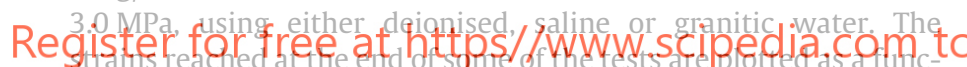
tion of the vertical pressure in Fig. 6. The influence of the initial dry density of the bentonite and of the load applied during saturation is clear: under a given vertical load the samples of higher initial dry

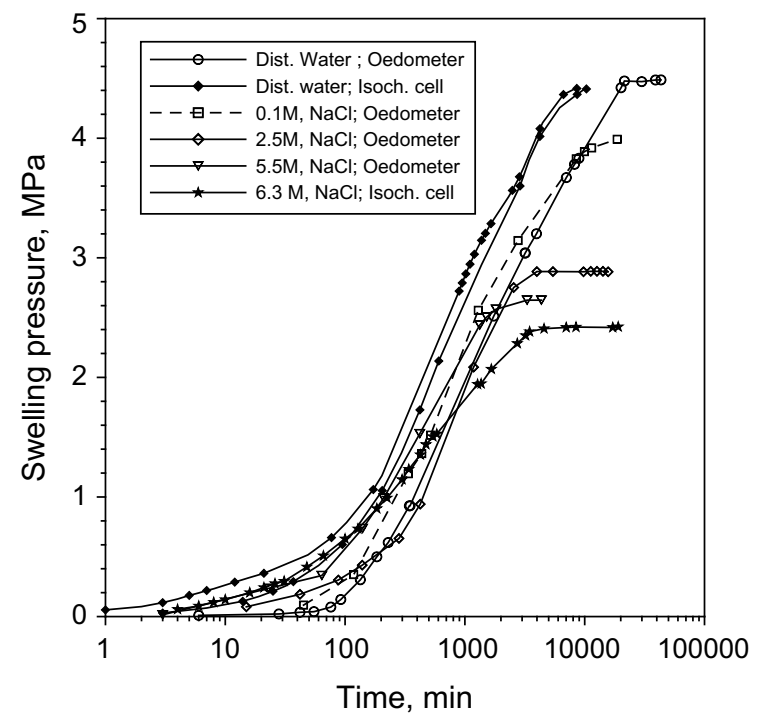

Fig. 5. Evolution of swelling pressures measured using different solutions $\left(\rho_{\mathrm{d}} 1.65 \mathrm{~g} / \mathrm{cm}^{3}\right)$

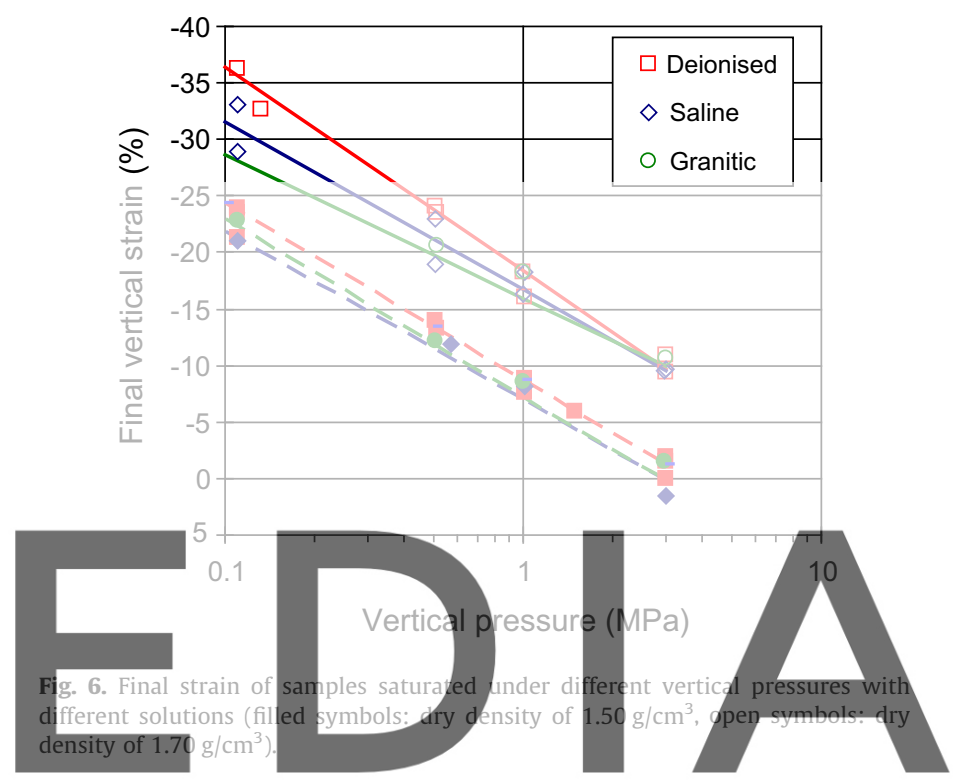

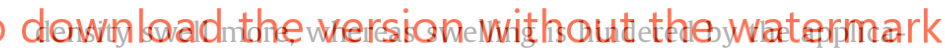
tion of high vertical loads. The samples with a dry density of $1.5 \mathrm{~g} / \mathrm{cm}^{3}$ and saturated under a vertical load of $3 \mathrm{MPa}-$ which is close to its swelling pressure, according to Eq. (3) - experienced compression when the vertical load was applied and small collapses at the beginning of the saturation. The average duration of the tests, which is related to the time needed for stabilisation of the swelling strain, was 18 days for the tests performed with deionised water, 13 days for the tests performed with granitic water and 11 days for the tests performed with saline water. These values are also a qualitative indication of the permeability of the samples, which would be higher for those saturated with saline water.

Taking into account all the results, the following fittings between final swelling strain $(\varepsilon, \%)$ and vertical pressure $(\sigma, \mathrm{MPa})$ as a function of the initial dry density $\left(\rho_{\mathrm{d}}, \mathrm{g} / \mathrm{cm}^{3}\right)$ were found and are also plotted in the figure (Lloret et al., 2004).

For deionised water:

$\varepsilon=\left(5.40 \rho_{\mathrm{d}}-1.32\right) \ln \sigma+\left(-48.25 \rho_{\mathrm{d}}+63.69\right)$

For saline water:

$\varepsilon=6.47 \ln \sigma+\left(-48.71 \rho_{\mathrm{d}}+66.13\right)$

For granitic water:

$\varepsilon=\left(-6.49 \rho_{\mathrm{d}}+16.53\right) \ln \sigma+\left(-43.59 \rho_{\mathrm{d}}+58.14\right)$

A slightly higher swelling capacity was observed in samples saturated with deionised water (14\% on average for samples saturated with saline water), but there is no distinct behaviour between the samples saturated with the low-salinity solutions. 

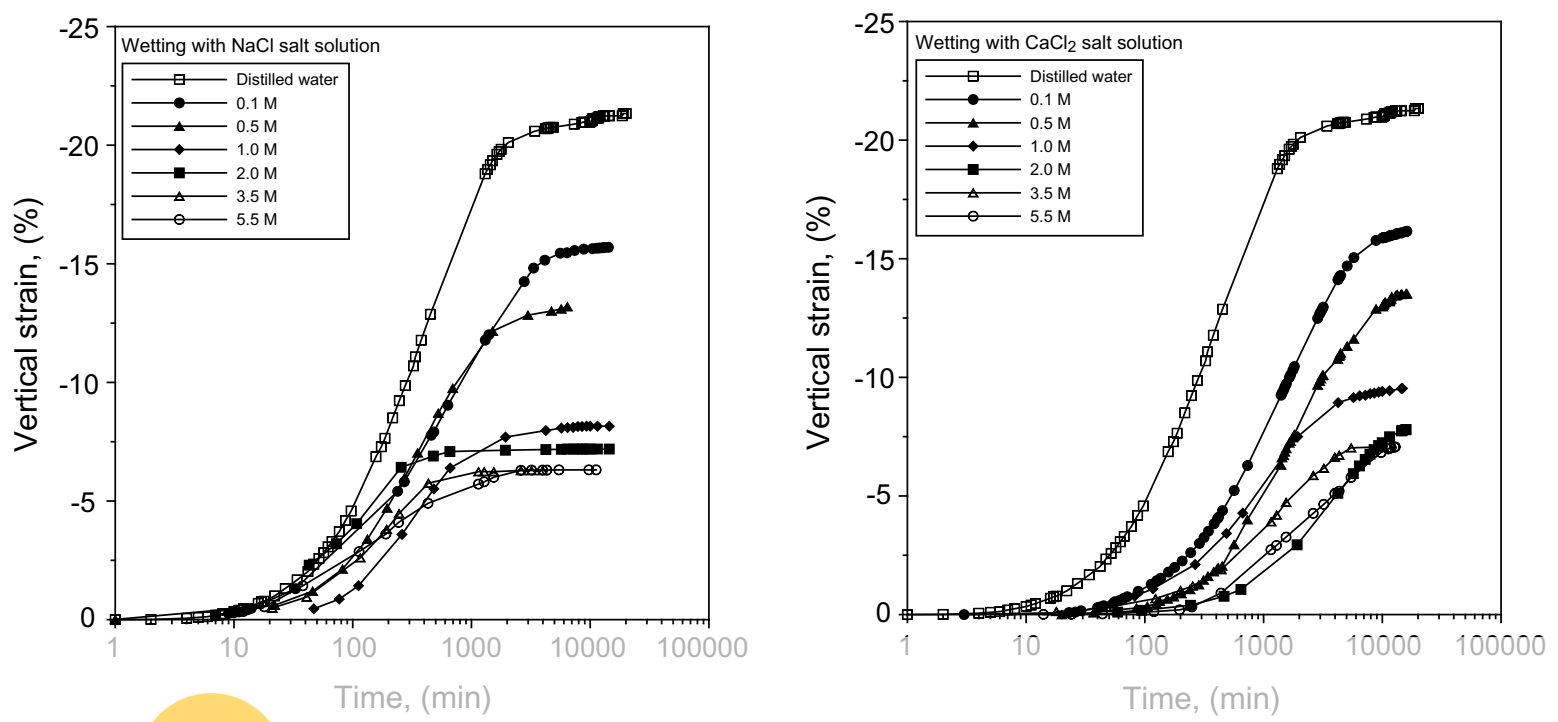

Fig. 7. Evolution of swelling strains during wetting under a vertical load of $0.5 \mathrm{MPa}$ with different solutions (initial $\rho_{\mathrm{d}} 1.65 \mathrm{~g} / \mathrm{cm}^{3}$ ).

4.2.2. Tests with high-salinity solutions

In order to evaluate the effect of high-salinity on swelling strains, swelling tests were performed in conventional oedometers,

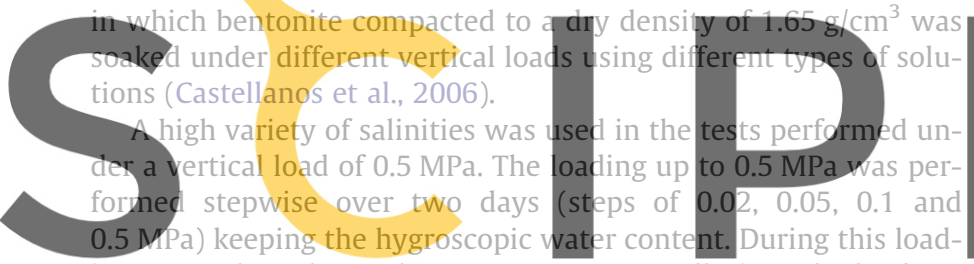
ing stage, the volume changes were very small, since the load applied was lower than the compaction stress (about $23 \mathrm{MPa}$ ) and

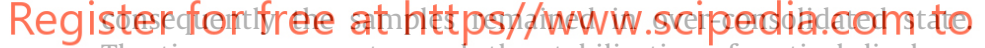
The time necessary to reach the stabilisation of vertical displacements during wetting was about 5 days, but this stage was extended to two weeks. The evolution of volumetric strains during wetting is presented in Fig. 7 for vertical stresses of $0.5 \mathrm{MPa}$. When the vertical stress applied during wetting was $2 \mathrm{MPa}$, the samples experienced an initial collapse eventually followed by the swelling of the microstructure. Fig. 8 shows the values of the final swelling strains. The values computed with Eqs. (4)-(6) (deionised, saline and granitic water, respectively) have also been included. It can be seen that the swelling capacity decreases significantly with

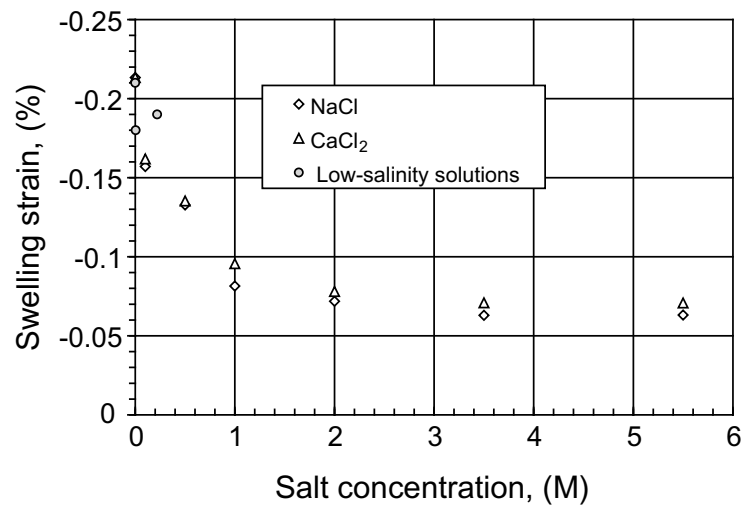

Fig. 8. Variation of swelling strains due to wetting with different solutions under a vertical stress of $0.5 \mathrm{MPa}$ (initial dry density $1.65 \mathrm{~g} / \mathrm{cm}^{3}$ ) (modified from Lloret and Villar, 2007). salinity and that the samples wetted with $\mathrm{CaCl}_{2}$ solutions swell slightly more than those wetted with $\mathrm{NaCl}$. Also, the swelling strain value obtained with Eq. (5) for a sample with an initial dry

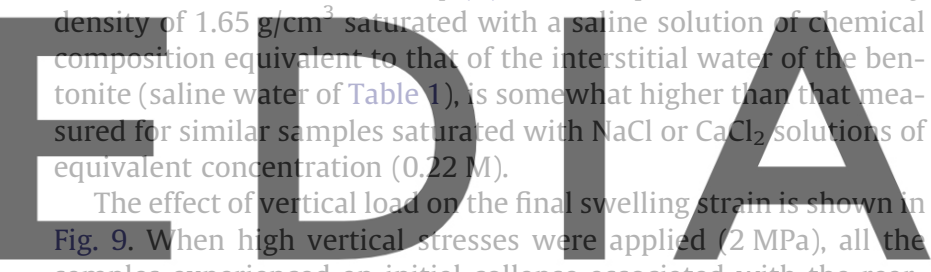
samples experienced an initial collapse associated with the rearrangement of the macrostructure, that was recovered afterwards.

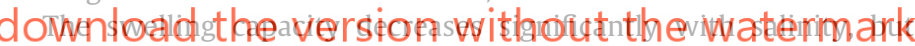
the differences in the swelling strains tend to be smaller when the vertical stress increases. In particular, the swelling strains of the bentonite compacted to a diy density of $1.65 \mathrm{~g} / \mathrm{cm}^{3}$ decreased to almost half its initial value when $2 \mathrm{M} \mathrm{CaCl}_{2}$ and $\mathrm{NaCl}$ solutions were used as saturating fluids. For higher concentrations the swelling capacity barely changed.

\subsection{Compressibility}

Once the bentonite was saturated in the swelling tests performed under a vertical load of $0.5 \mathrm{MPa}$ and described in the previous section, it was loaded under oedometric conditions up to $2 \mathrm{MPa}$, in order to evaluate the bentonite stiffness and permeability. After the saturation stage, the vertical load was increased up to 1 and then $2 \mathrm{MPa}$. The unloading stage was performed in two steps. The evolution over time of vertical settlements measured after the application on the saturated samples of a vertical load of $2 \mathrm{MPa}$ is shown in Fig. 10 for samples saturated with $\mathrm{NaCl}$ solutions. Similar trends were obtained for samples saturated with $\mathrm{CaCl}_{2}$ solutions. Despite the dispersion of the results, it is possible to observe that the samples saturated with solutions containing high concentration of ions are less deformable and consolidate more rapidly than the samples saturated with low-salinity solutions. The higher compressibility of samples saturated with low-salinity solutions could be also a consequence of the higher porosity they reach after saturation. Fig. 11 shows the results of the soaking under load $0.5 \mathrm{MPa}$ and compression stages in terms of final void ratios.

The parameters of the Terzaghi's 1-D consolidation model $C_{v}$ and $E_{m}$ obtained by backanalysis of the temporal evolution of set- 

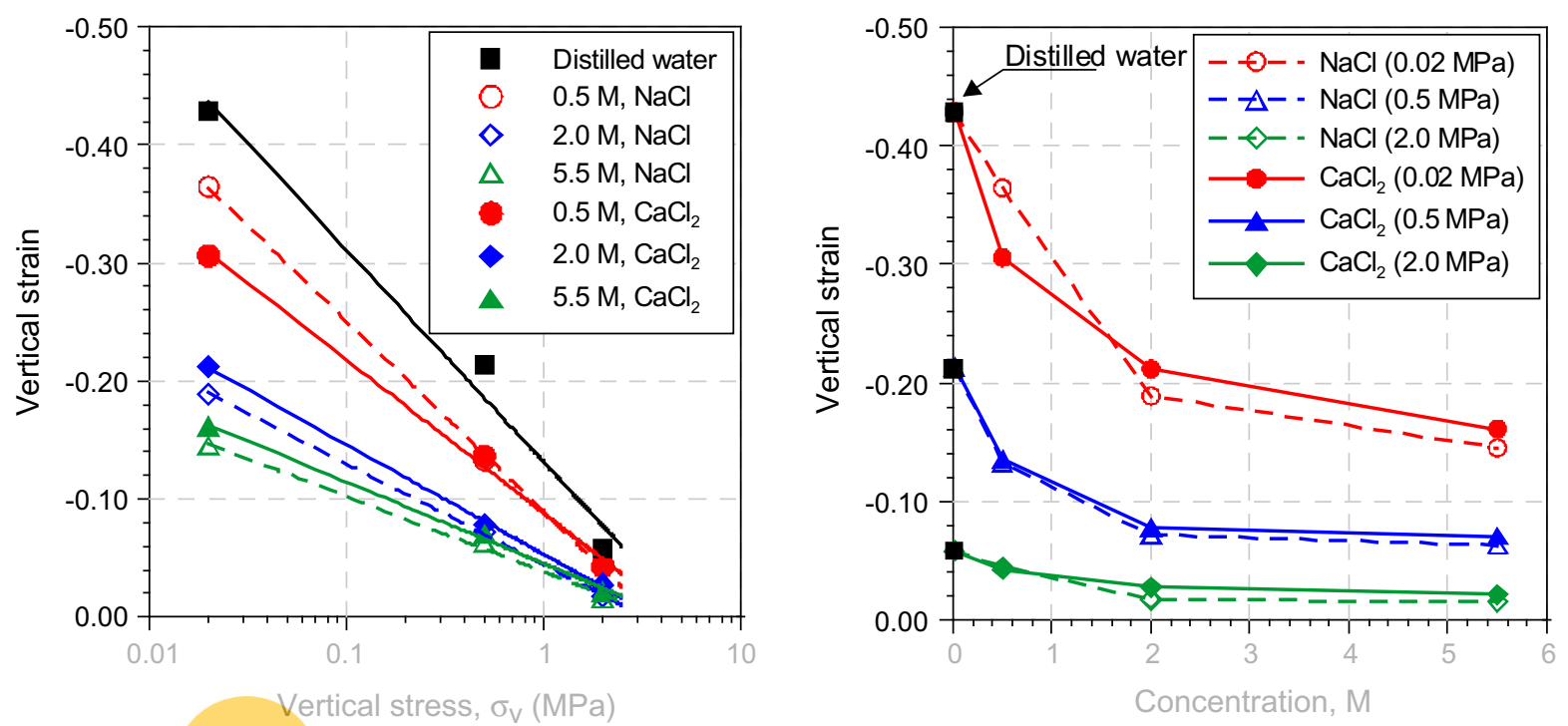

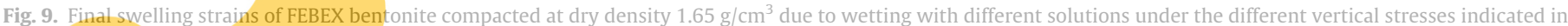
the legend (Castellanos et al., 2006).

time (s)

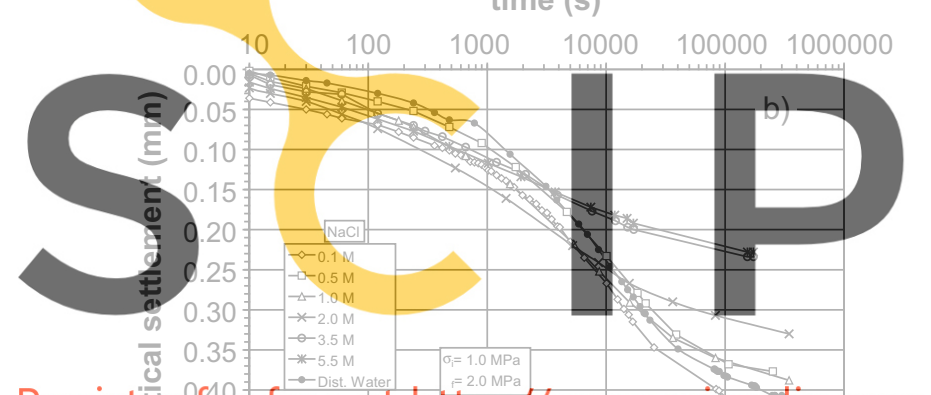

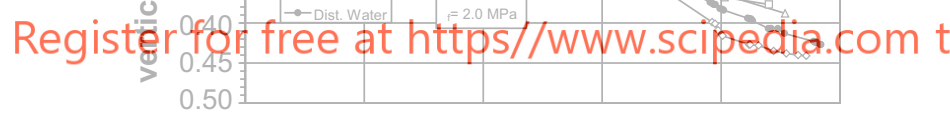

Fig. 10. Evolution of vertical settlements due to loading under oedometer conditions of samples saturated with solutions of $\mathrm{NaCl}$ of different concentrations. Loading from 1.0 to $2.0 \mathrm{MPa}$. tlements are given in Fig. 12. The increase in the coefficient of consolidation $\left(C_{v}\right)$ and the drained constrained stiffness $\left(E_{m}\right)$ with increasing solute concentrations is clearly observed. This increase cannot be attributed only to solute effects, in fact, the different
structure (void ratio) of the samples after saturation plays al sighif-
icant role in the value of these parameters. No clear vafiation of c-
with the salinity of the solution was observed.
4.4. Permeability

4.4.1. Tests with low-salinity solutions
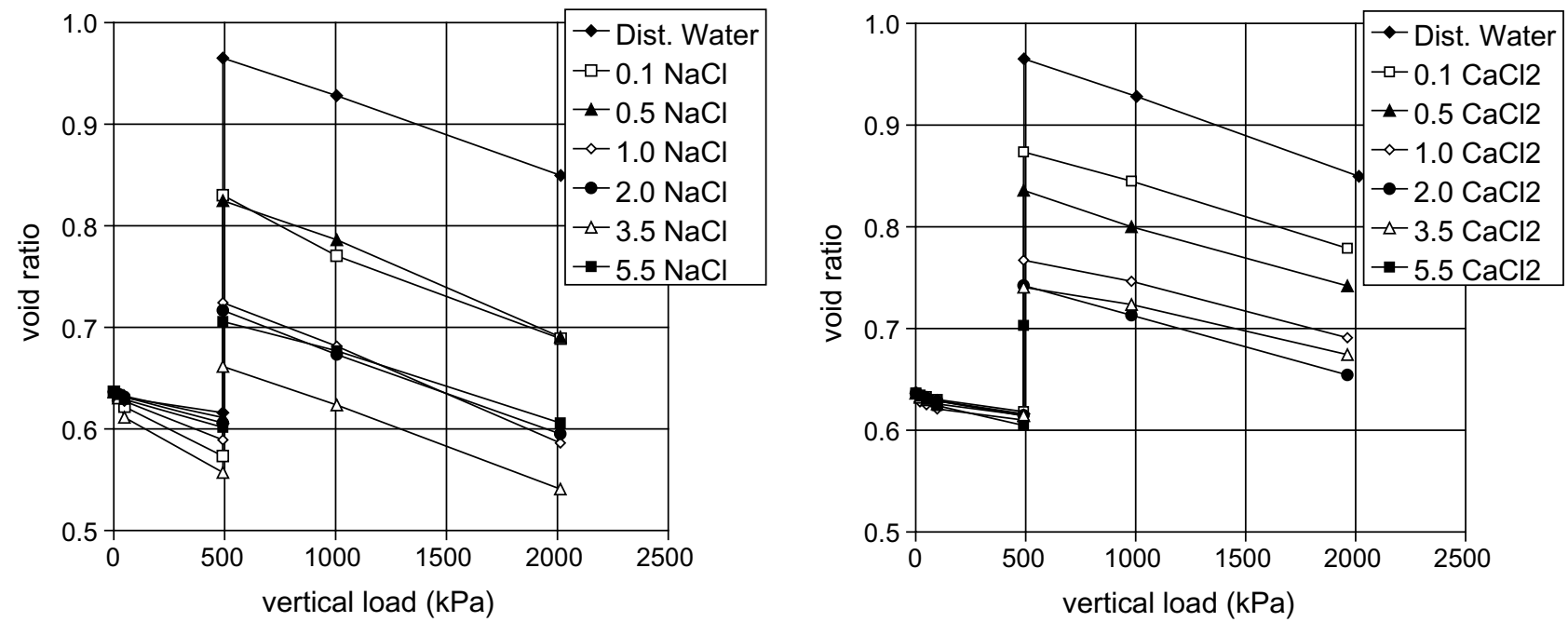

Fig. 11. Changes in void ratio during soaking under load $0.5 \mathrm{MPa}$ and compression up to $2 \mathrm{MPa}$ using different solutions (initial $\rho_{\mathrm{d}} 1.65 \mathrm{~g} / \mathrm{cm}^{3}$ ). 

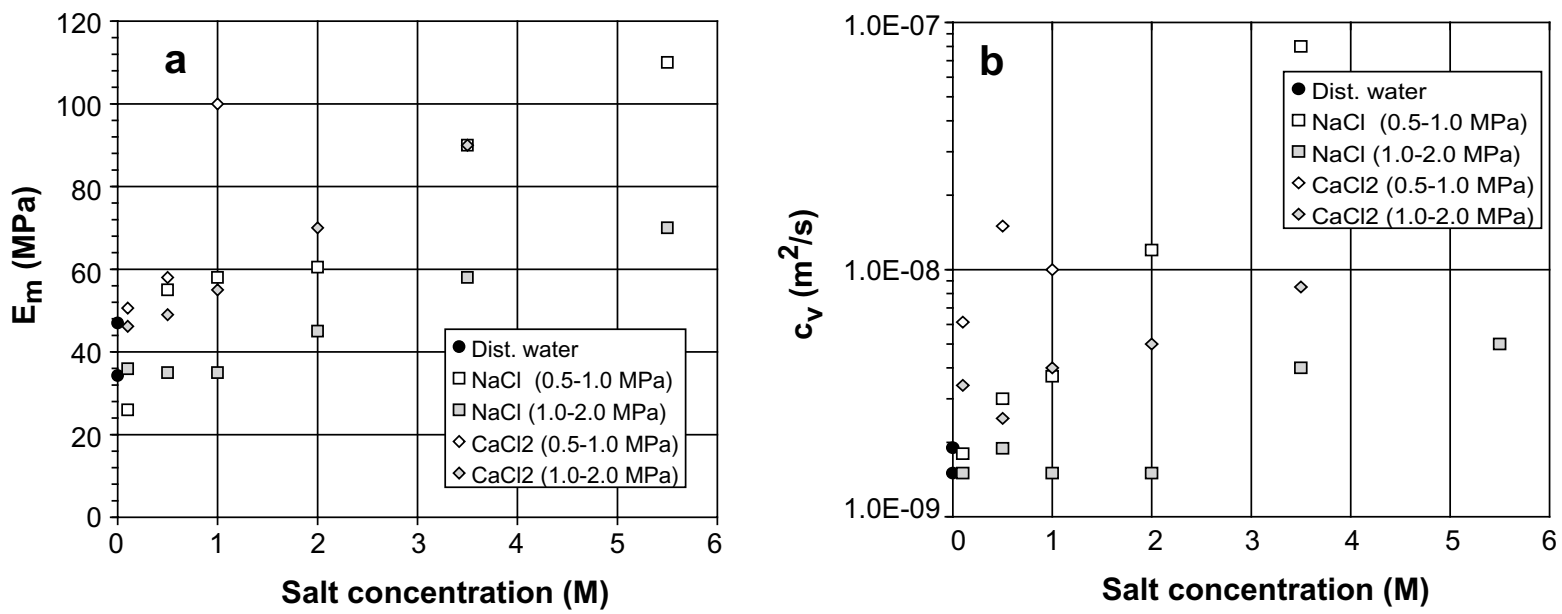

Fig. 12. Variation with salinity of parameters obtained from oedometer tests on samples saturated with different solutions (Lloret et al., 2004).

than those expected for a sample of the same density tested with deionised water, and in addition, they show greater dispersion. This higher permeability to saline water with respect to that expected for deionised water is more pronounced for low densities.

4.4.2. Tests with high-salinity solutions
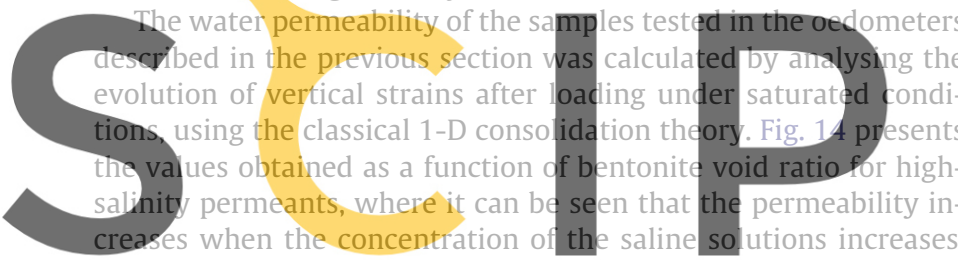

especially for high values of saline concentration. For a given void ratio, the permeability to $\mathrm{NaCl}$ solutions is higher than that for

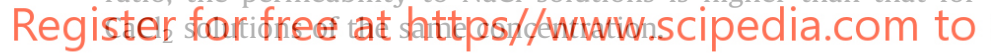

\section{Discussion}

Although it is generally accepted that the swelling pressure decreases with the saline content of the solution, the influence of the

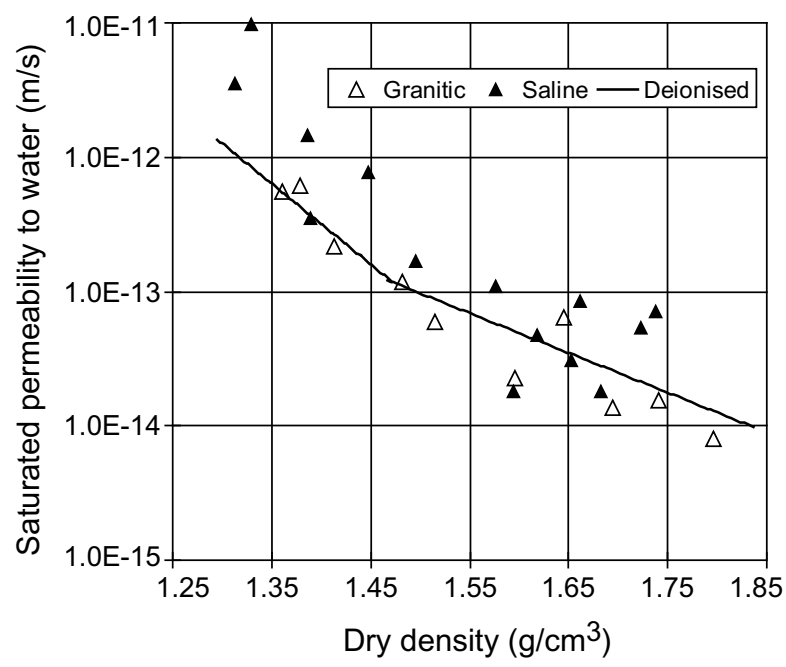

Fig. 13. Hydraulic conductivity for granitic or saline water versus the dry density of the clay and fittings obtained for deionised water (Eqs. (1) and (2)) (Lloret and Villar, 2007). salinity of the solution on the value of the swelling pressure has been considered negligible or small for montmorillonite compacted at high-density, especially in the case of Ca-montmorillonite (Pusch, 1994). Karnland et al. (2005) measured reductions of the swelling pressure of MX-80 bentonite (a Na-montmorillonite) with the salinity of the saturating fluid, which were relatively low-

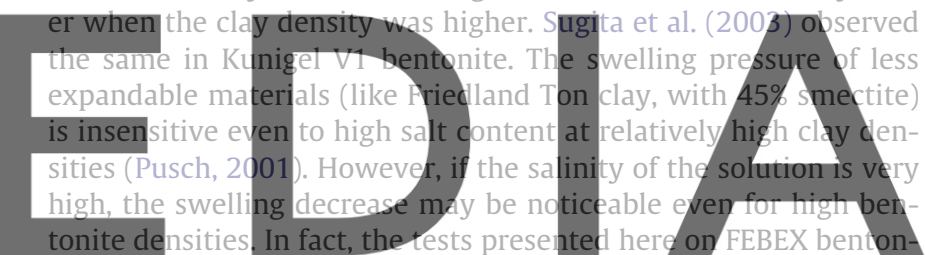

ite show that the swelling pressure of the bentonite compacted to a dry density of $1.65 \mathrm{~g} / \mathrm{cm}^{3}$ decreases to almost half its initial value

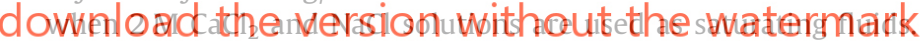
For higher concentrations, the swelling capacity barely changes. This reduction could be related to an increase in osmotic suction. However, it shail be mentioned that the osmotic suction associated with the solution $6.3 \mathrm{M} \mathrm{NaCl}$ and with the solution $4.2 \mathrm{M} \mathrm{CaCl}_{2}$ is equal to $40 \mathrm{MPa}$ in both cases (see Section 2), but the reduction of swelling pressure is bigger when $\mathrm{NaCl}$ is used as a solute. For low salinites $(0.004 \mathrm{M}$, granitic water), the swelling pressure of the bentonite seems not to be affected in the dry density range from 1.4 to $1.7 \mathrm{~g} / \mathrm{cm}^{3}$.

Bentonite develops slightly lower swelling strains upon saturation with low-concentrated solutions (up to $0.8 \%$ salinity) than with deionised water. The reduction of the swelling strains for higher salinities is clearer and can be explained by considering that the $\mathrm{NaCl}$ or $\mathrm{CaCl}_{2}$ solutions cause an increase in electrolyte concentration near the clay particle surfaces, diminishing the thickness of the double layer and the swelling potential. Also, samples wetted with $\mathrm{CaCl}_{2}$ solutions swell slightly more than those wetted with $\mathrm{NaCl}$ with the same molarity.

The swelling curves shown in Fig. 7 indicate that the samples saturated with low-salinity solutions, develop a quick initial primary swelling as well as a subsequent slower secondary swelling, whereas the samples saturated with high-salinity solutions display a smaller primary swelling and a small to inexistent secondary swelling. Rao et al. (2006) consider that the primary swelling of expandable clays is linked to the rate of matric suction dissipation (which is conditioned by the size of the clay pores), whereas secondary swell is controlled by diffusion of salts and adsorptiondesorption reactions. In the case of high-salinity solutions, the diffusion of salts from the saturating solution into the clay particles 


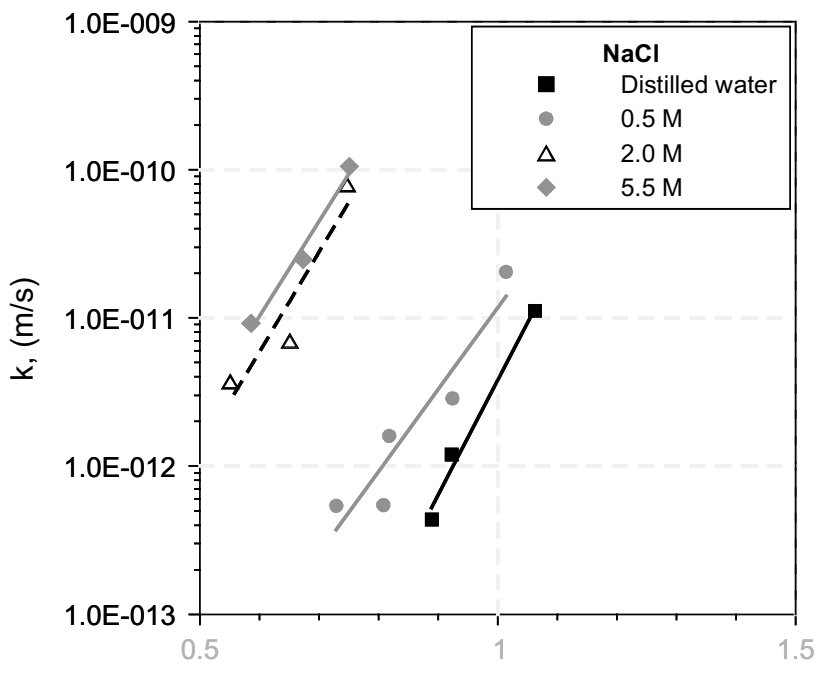

Void ratio, e

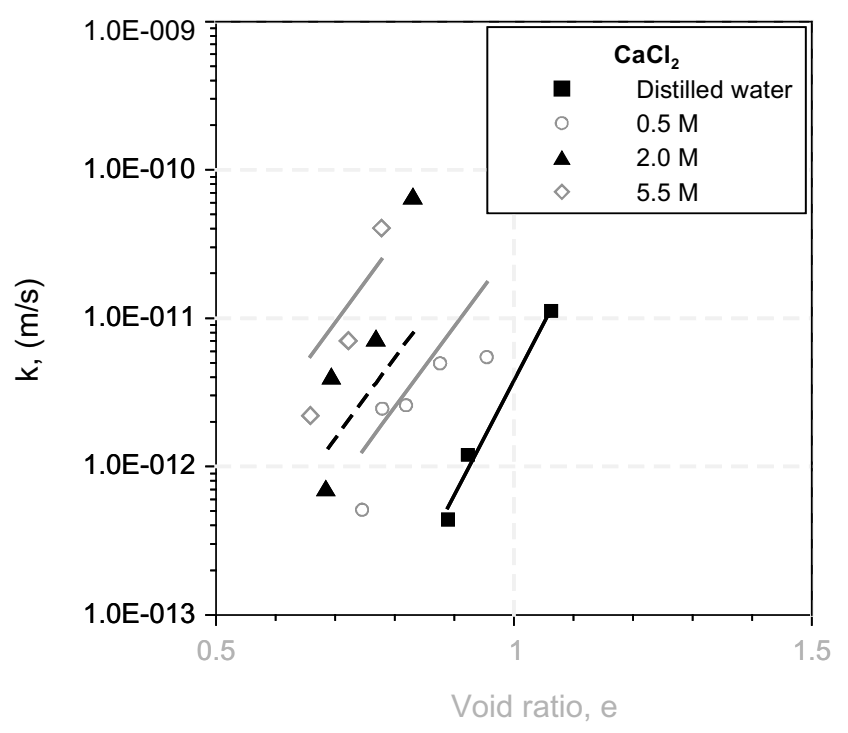

would cause osmotic consolidation that would, not only decrease the primary swelling, but also counteract or hinder the secondary swelling.

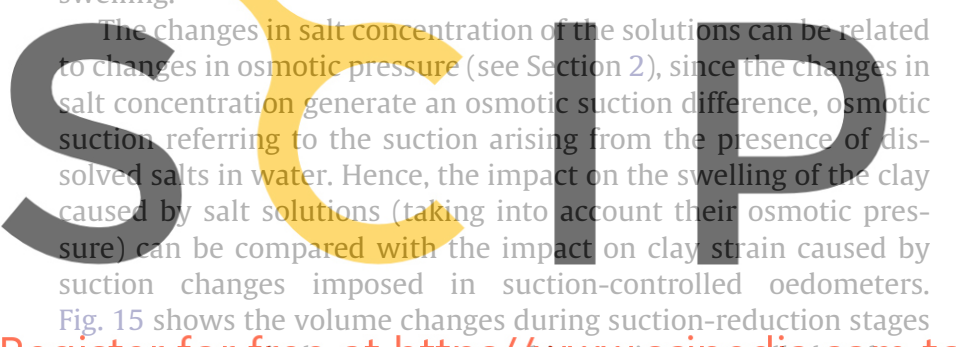

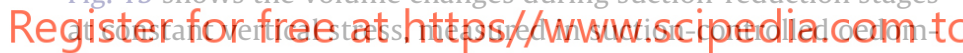

eters that use the vapour control technique for suctions higher than $14 \mathrm{MPa}$ and the axis translation technique for lower suctions (Lioret et ai., 2004). The same figure inciudes the sweiling strain measured in the soaking tests using different salt solutions (shown previously in Fig. 9), considering the value of the osmotic suction associated to each of them. It seems that the magnitude of the two types of strains is comparable.

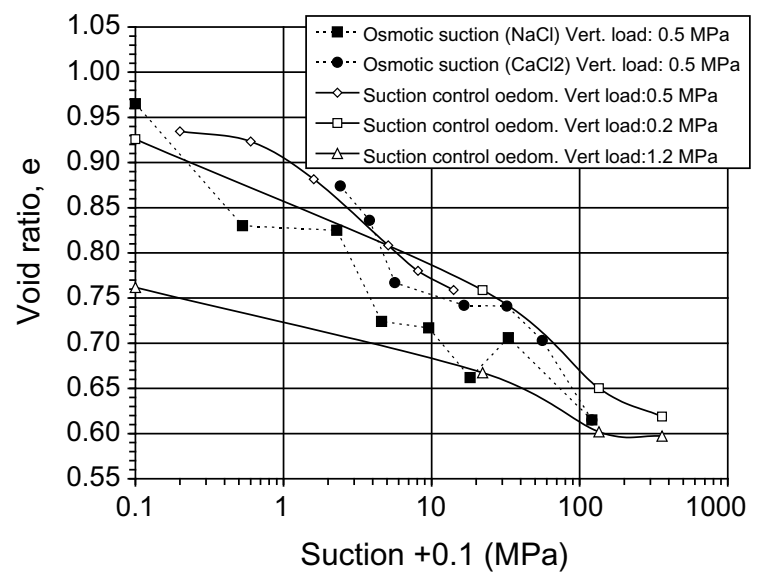

Fig. 15. Comparison between swelling strains due to suction-reduction and strains due to soaking with different $\mathrm{NaCl}$ and $\mathrm{CaCl}_{2}$ solutions under different vertical loads (Lloret et al., 2004).
The effect of salinity on the hydraulic conductivity of the highly compacted saturated FEBEX bentonite is not very important when the permeant is a low-salinity solution. For the bentonite saline water $(0.22 \mathrm{M}, 0.8 \%$ salinity) the permeability values obtained
were $184 \%$ higher on average than those expected for a sanple
of the same density tested wity deionised water, and they showed
greater dispersion. This higher permeability to saline yater is more
significant for low densities. The increase in permeabinity with
salinity for high-salinity perneants (up to $5.5 \mathrm{M}$ ) is much obvious
(up to two orders of magnitude), especially when the stress level is low and when $\mathrm{Na}$ is the predominant cation in the solution (Fig. 14).

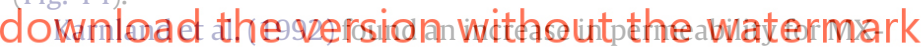

80 bentonite of half an order of magnitude when the salinity of the permeant increases from $0 \%$ to $3.5 \% \mathrm{NaCl}$. Villar (2005) found that the hydrauilic conductivity of IVX-80 bentonite was $135 \%$ higher for saline water ( $0.5 \%$ salinity) than for deionised water. These variations are in the order of those shown here for the FEBEX bentonite under similar conditions. However, the hydraulic conductivity of less expandable materials (such as Friedland Ton clay, with $45 \%$ of smectite) is more affected by the changes in the salinity of the permeant, increasing up to two orders of magnitude when salinity rises from $0 \%$ to $20 \%$ (Pusch, 2001), sodium giving place to a higher increase in permeability than calcium.

It is an accepted fact that the type of water used as a permeating agent, and especially its salinity, has an impact on the coefficient of permeability of clay (Klute, 1965; Olsen, 1962). The increase in permeability with the salinity of the permeating fluid was emphasised by several authors. In particular, it has been reported that the permeability of clays and clayey sandstones increases with the concentration of $\mathrm{NaCl}$ in the water. Rolfe and Aylmore (1977) attribute the changes in permeability observed in their tests with montmorillonite and illite to changes in ion distribution associated with variations in the cation exchange complex and to the concentration of the electrolyte used as permeating agent. There are various mechanisms that contribute to these changes, among them: (1) alterations in pore dimension distribution as a result of variations in swelling pressure in the clay matrix, (2) variations in the mobility of the molecules of water associated with the exchangeable cations adsorbed on the surfaces or forming diffuse double layers, and (3) alterations in the viscous behaviour of the structure of the water. As a result of these mechanisms, when the 
concentration of the electrolyte increases there is a reduction in the swelling capacity of the clay particles, the size of the flow channels increasing to the detriment of the number of small channels, this causing flow - and therefore, permeability - to increase. On the contrary, the higher development of diffuse double layers on reduction of the concentration of the electrolyte causes a decrease in permeability, because the size of the flow channels decreases. In expansive materials, it is the intrinsic permeability of the material itself that is altered by interactions between the fluid and the solid, and the largest variations in permeability with the composition of the fluid are found in clays with high content of montmorillonite (McNeal and Coleman, 1966). According to the diffuse double layer theory, its thickness decreases as the concentration of water in the pores increases, as a result of which, for a given porosity, the effective porosity of the clay would increase with increasing concentration of the solution, with the corresponding increase in permeability. In their studies with Na-montmorillonite, Studds et al. (1998) observed a clear increase in hydraulic conductivity as the saline concentration of the permeating agent increases, which they attributed to modifications induced by the latter in the effective porosity of the clay. The reduction of effective porosity with decreasing salinity of the permeating agent would result from occupation of the pore space by the bound water (DDL), the viscosity of which is higher than that of free water.

\section{Conclusions}

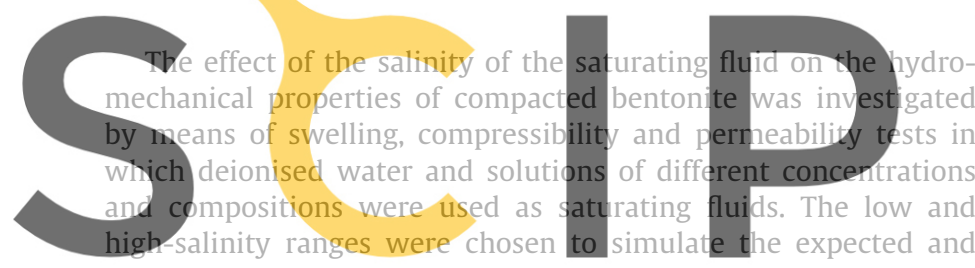
the extreme conditions in a high-level radioactive waste repository excavated in crystalline or clay host rocks.

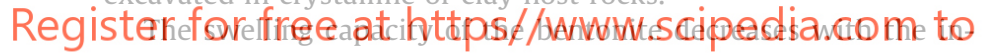
crease in salinity of the pore water, although this change is less patent for high vertical loads and high densities, and when the salinity of the solution is very low. For an equivalent concentration and in the high-salinity range, sodium seems to reduce more the swelling capacity than calcium. In addition, the secondary swelling of samples saturated with high-salinity solutions is reduced or disappears.

The samples saturated with solutions containing high concentration of ions are less deformable and consolidate more rapidly than the samples saturated with low-salinity solutions.

The effect of salinity on the hydraulic conductivity of the highly compacted saturated FEBEX bentonite is not very important when the permeant is a low-salinity solution. However, the saturated permeability of the compacted bentonite clearly increases when high-salinity permeants are used. This higher permeability to saline water is more significant for low densities and when the stress level is low. For the high-salinity range, the permeability increases more when sodium is the predominant cation in the solution. This behaviour is contrary to what it is observed at saline concentrations of $0.5 \mathrm{M}$, in which a higher permeability is observed at low void ratios when calcium is the predominant cation. This higher permeability has been usually associated with microstructural changes and the tendency of calcium solutions to form denser aggregates, leaving larger macropores in between them. Further studies of these aspects are required to explain the unexpected higher permeability with sodium solutions at high concentrations.

For the salinities reasonably expected in the groundwater of a HLW repository excavated in crystalline or clay host rocks, the swelling and permeability properties of the FEBEX compacted ben- tonite will remain in the range of acceptable values. Much higher salinities (above $2 \mathrm{M}$ ) would drastically reduce the performance of the bentonite barrier.

\section{Acknowledgements}

Work co-funded by ENRESA and the European Commission and performed as part of the Fourth and Fifth EURATOM Framework Programme, key action Nuclear Fission (1998-2002), Projects FEBEX (EC Contract FI4W-CT95-006) and FEBEX II (EC Contract FIKWCT-2000-00016). The support of the Spanish Ministerio de Ciencia y Tecnología through the research Grant BTE-2002-02161 and of the Direcció General de Recerca of the Generalitat de Catalunya through the research grants ACI2002-42 and ACI2003-35 is acknowledged. The laboratory work at Centro de Investigaciones Energéticas, Medioambientales y Tecnológicas (CIEMAT, Madrid) was performed by J. Aroz and R. Campos.

\section{References}
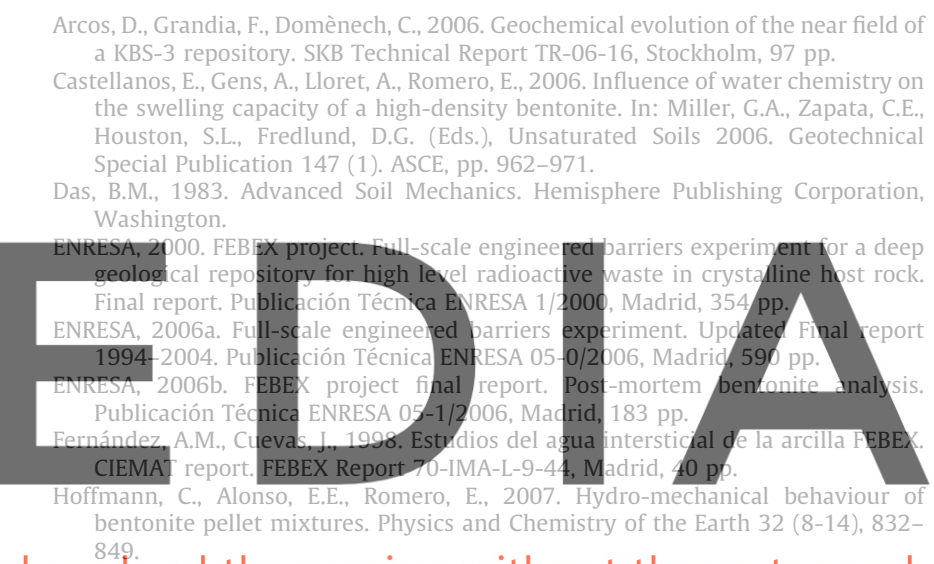

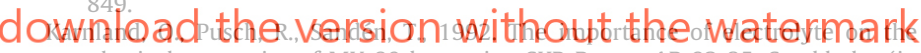
physical pro
Swedish)

Karnland, O., Muurinen, A., Karlsson, F., 2005. Bentonite swelling pressure in NaCl solutions - experimentally determined data and model calculations. In: Alonso, E.E., Ledesma, A. (Eds.), Advances in Understanding Engineered Clay Barriers. Balkema, Leiden, pp. 241-256.

Klute, A., 1965. Laboratory measurements of hydraulic conductivity of saturated soil. In: Black, C.A. (Ed.), Methods of Soil Analysis. Agronomy Series, vol. 9. American Society of Agronomy, Inc., pp. 210-221.

Lambe, T.W., Whitman, R.V., 1979. Soil Mechanics. John Wiley \& Sons, New York.

Lloret, A., Villar, M.V., 2007. Advances on the knowledge of the thermo-hydromechanical behaviour of heavily compacted FEBEX bentonite. Physics and Chemistry of the Earth, Parts A/B/C 32 (8-14), 701-715.

Lloret, A., Villar, M.V., Sánchez, M., Gens, A., Pintado, X., Alonso, E., 2003. Mechanical behaviour of heavily compacted bentonite under high suction changes. Géotechnique 53 (1), 27-40.

Lloret, A., Romero, E., Villar, M.V., 2004. FEBEX II project. Final report on thermohydro-mechanical laboratory tests. Publicación Técnica ENRESA 10/2004, ENRESA, Madrid, 165 pp.

McNeal, B.L., Coleman, N.T., 1966. Effect of solution composition on soil hydraulic conductivity. Soil Science Society of America Proceedings, 308-317.

Olsen, H.W., 1962. Hydraulic flow through saturated clays. In: Ninth Nat. Conf. on Clays and Clay Minerals. Pergamon, Oxford, pp. 170-182

Pusch, R., 1994. Waste Disposal in Rock. Developments in Geotechnical Engineering, vol. 76. Elsevier, Amsterdam. 490 pp.

Pusch, R., 2001. Experimental study of the effect of high porewater salinity on the physical properties of a natural smectitic clay. SKB Technical Report TR-01-07, Stockholm, 35 pp.

Rao, S.M., Thyagaraj, T., Thomas, H.R., 2006. Swelling of compacted clay under osmotic gradients. Géotechnique 56 (10), 707-713.

Rolfe, P.F., Aylmore, L.A.G., 1977. Water and salt flow through compacted clays: I. Permeability of compacted illite and montmorillonite. Soil Science Society of America Journal 41, 489-495.

Romero, E., 1999. Characterisation and thermo-hydro-mechanical behaviour of unsaturated Boom-clay: an experimental study. Ph.D. Thesis, Universidad Politécnica de Cataluña, Barcelona, 405 pp.

Studds, P.G., Stewart, D.I., Cousens, T.W., 1998. The effects of salt solutions on the properties of bentonite-sand mixtures. Clay Minerals 33, 651-660. 
Sugita, Y., Chijimatsu, M., Suzuki, H., 2003. Fundamental properties of bentonite pellet for prototype repository project. In: Proc. Int. Workshop Large scale field tests in granite. Advances in understanding and research needs, Universitat Politècnica de Catalunya-ENRESA, Sitges, November 12-14th, 2003.

Turrero, M.J., Peña, J., 2003. Arcilla española de referencia. Integración de resultados de la formación geológica: sondeos IC-1 y SS-1. CIEMAT/DIAE/54460/3/03, versión 1. ENRESA 2003, GTI 2- Descripción del Emplazamiento (in Spanish).

Villar, M.V., 2002. Thermo-hydro-mechanical characterisation of a bentonite from Cabo de Gata. A study applied to the use of bentonite as sealing material in high level radioactive waste repositories. Publicación Técnica ENRESA 01/2002, Madrid, $258 \mathrm{pp}$.

Villar, M.V., 2005. MX-80 bentonite. Thermo-hydro-mechanical characterisation performed at CIEMAT in the context of the prototype project. Informes Técnicos Ciemat, 1053, Madrid, 39 pp.

Villar, M.V., Lloret, A., 2001. Variation of the intrinsic permeability of expansive clay upon saturation. In: Adachi, K., Fukue, M. (Eds.), Clay Science for Engineering. Balkema, Rotterdam, pp. 259-266. 